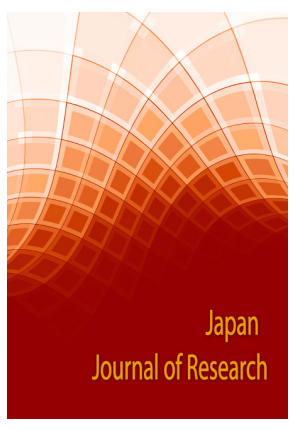

Correspondence

Mahmoud Trabelsi

Laboratoire de Chimie Organique (LR17ES08), Faculté des Sciences de Sfax, Université de Sfax, B.P. 1173, 3038 Sfax, Tunisie.

E-mail: Mah.Trabelsi@fss.rnu.tn

- Received Date: 07 Dec 2021

- Accepted Date: 15 Dec 2021

- Publication Date: 24 Dec 2021

Copyright

(c) 2021 Science Excel. This is an openaccess article distributed under the terms of the Creative Commons Attribution 4.0 International license.

\title{
Green synthesis of biologically active chalcones by Claisen-Schmidt condensation under mild conditions
}

\author{
Manef Chtourou' ${ }^{1}$ and Mahmoud Trabelsi ${ }^{1 *}$ \\ 1 Laboratoire de Chimie Organique (LR17ES08), Faculté des Sciences de Sfax, University of Sfax, Tunisia
}

Trans-chalcones are a family of aromatic ketones with two aromatic groups bridged by an enone linkage $\left(\mathrm{Ar}-\mathrm{COCH}=\mathrm{CH}-\mathrm{Ar} \mathbf{r}^{\prime}\right)$ [1]. Chalcones that derived from nature exist mostly as colors of petal and furthermore have been established in the heartwood, leaf, bark, fruit, and root of a range of plants and botanicals [2].

Plants containing chalcones, for instance, the Glycyrrhiza, Piper, Angelica, and Ruscus genus, have long been utilized as therapeutic remedies [2-4].

Several studies evaluated the biological activity of naturally occurring and synthetic chalcones and revealed them to be antimalarial [5,6], anti-cancer [7], anti-leishmanial [8], anti-inflammatory [9], antimitotic [10], antituberculosis [11], cardiovascular [12] and cell differentiation inducing [13].

In recent years, the green routes, in particular the solvent free synthesis of chalcones, have been gained special attention. The solvent free reactions avoid organic solvents leads to a clean, efficient and economical technology. It has many advantages such as high efficiency and selectivity, easy separation and purification, mild reaction conditions and environmental acceptability. Recently, the combination of the solvent-free condition and the use of heterogeneous catalysts have emerged as an eco-friendly alternative of great importance due to simplification of work up technique [14].

Different heterogeneous acid or basic catalysts have been investigated in the synthesis of transchalcones, such as $\mathrm{Ca}$ (OTf)2-NBu4.BF4 [15], potassium hydroxide impregnated silica gel [16], Bamboo char sulfonic acid [17], amino grafted zeolites [18], commercial acid-clays [1,19] and Amberlyst-15 under solvent free condition [14].

In the presence of $\mathrm{Ca}(\mathrm{OTf}) 2-\mathrm{NBu} 4 . \mathrm{BF} 4$, substituted acetophenones and benzaldehydes were coupled in situ to afford their corresponding chalcones in excellent yields. This method showed a broad range of substrate tolerance and mild operational conditions [15].

A synthesis of chalcone from aryl methyl ketone and substituted benzaldehyde was realized in green catalyst fly ash: $\mathrm{H} 2 \mathrm{SO} 4$ by microwave irradiation at 160-800 watt [20]. Another method assisted by microwave irradiation was reported [21]. In this method, a new solid acid catalyst ( $\mathrm{FeCl} 3 /$ bentonite) has been used for the synthesis of aryl chalcones under solvent-free conditions.

An improved solvent-free method of synthesis of trans-chalcones was based on ultrasound irradiation of the reagents (aryl methyl ketones and aryl aldehydes) in presence of KSF montmorillonite as catalyst. The trans-chalcones were synthesized in high yields (85-95\%) and excellent selectivity in a short reaction time at $100^{\circ} \mathrm{C}$ [1]. In the presence of commercial acid resins (Amberlite-200C and Amberlyst-15) as catalysts, the synthesis of different substitued chalcones under ultrasound irradiation was achieved in a short reaction time (60 minutes) and gave excellent yields (77-98\%) [14]. DuranValle et al. [22] reported that when one of the phases is a solid the ultrasonic irradiation has several additional enhancement effects, which are particularly convenient when the solid acts as catalyst. In general, the sonication presents beneficial effects on the chemical reactivity, such as to accelerate the reaction, to reduce the induction period and to enhance the catalyst efficiency.

\section{References}

1. Chtourou M, Abdelhédi R, Frikha $M H$, Trabelsi M. Solvent free synthesis of 1,3-diaryl2-propenones catalyzed by commercial acidclays under ultrasound irradiation. Ultrason Sonochem. 2010;17(1):246-249.

2. Schröder J. Comprehensive Natural Products Chemistry. Vol 1. Oxford: Elsevier; 1999. pp. 749-771.

3. Chatzopoulou M, Pegklidou K, Papastavrou N, Demopoulos VJ. Development of aldose reductase inhibitors for the treatment of inflammatory disorders. Expert Opin Drug Discov. 2013;8(11):1365-1380.

4. Maccari R, Ottanà R. Targeting aldose reductase for the treatment of diabetes complications and inflammatory diseases: new insights and future directions. J Med Chem. 2015;58(5):2047-2067.

5. Liu M, Wilairat P, Go ML. Antimalarial alkoxylated and hydroxylated chalcones 
[corrected]: structure-activity relationship analysis. J Med Chem. 2001;44(25):4443-4452.

6. Domínguez JN, Charris JE, Lobo G, et al. Synthesis of quinolinyl chalcones and evaluation of their antimalarial activity. Eur J Med Chem. 2001;36(6):555-560.

7. Xia Y, Yang ZY, Xia P, Bastow KF, Nakanishi Y, Lee KH. Antitumor agents. Part 202: novel 2'-amino chalcones: design, synthesis and biological evaluation. Bioorg Med Chem Lett. 2000;10(8):699-701.

8. Zhai L, Chen M, Blom J, Theander TG, Christensen SB, Kharazmi A. The antileishmanial activity of novel oxygenated chalcones and their mechanism of action. J Antimicrob Chemother. 1999;43(6):793-803.

9. Hsieh HK, Tsao LT, Wang JP, Lin CN. Synthesis and antiinflammatory effect of chalcones. J Pharm Pharmacol. 2000;52(2):163-171.

10. Ducki S, Forrest R, Hadfield JA, et al. Potent antimitotic and cell growth inhibitory properties of substituted chalcones. Bioorg Med Chem Lett. 1998;8(9):1051-1056.

11. Lin YM, Zhou Y, Flavin MT, Zhou LM, Nie W, Chen FC. Chalcones and flavonoids as anti-tuberculosis agents. Bioorg Med Chem. 2002;10(8):2795-2802.

12. Furman C, Lebeau J, Fruchart J, et al. Di-tert-butylhydroxylated flavonoids protect endothelial cells against oxidized LDLinduced cytotoxicity. J Biochem Mol Toxicol. 2001;15(5):270278.

13. Park EJ, Park HR, Lee JS, Kim J. Licochalcone A: an inducer of cell differentiation and cytotoxic agent from Pogostemon cablin. Planta Med. 1998;64(5):464-466.

14. Lahyani A, Chtourou M, Frikha MH, Trabelsi M. Amberlyst-15 and Amberlite-200C: efficient catalysts for aldol and cross- aldol condensation under ultrasound irradiation. Ultrason Sonochem. 2013;20(5):1296-1301.

15. Halpani CG, Mishra S. Lewis acid catalyst system for ClaisenSchmidt reaction under solvent free condition. Tetrahedron Letters. 2020;61(31): 152175.

16. Natekar RS, Samant SD. Clay Minerals as Catalysts. Indian J Chem. Sect. B. 1994;30:313.

17. Xu Q, Yang Z, Yin D, Zhang F. Synthesis of chalcones catalyzed by a novel solid sulfonic acid from bamboo. Catal. Commun. 2008;9:1579-1582.

18. Perozo-Rondon E, Martın-Aranda RM, Casal B, et al. Sonocatalysis in solvent free conditions: An efficient ecofriendly methodology to prepare chalcones using a new type of amino grafted zeolites. Catal Today. 2006;114:183-187.

19. Ballini R, Bosica G, Maggi R, et al. Clay-catalysed solventless synthesis of trans-chalcones. Green Chem. 2001;3:178.

20. Thirunarayanan G, Mayavel P, Thirumurthy K. Fly-ash:H2SO4 catalyzed solvent free efficient synthesis of some aryl chalcones under microwave irradiation Spectrochimica Acta Part A: Molecular and Biomolecular Spectroscopy. 2012;91:18-22.

21. Muthuvel I, Dineshkuma S, Thirumurthy K, Thirunarayanan $\mathrm{G}$, A new solid acid catalyst $\mathrm{FeCl} 3$ /bentonite for aldol condensation under solvent-free condition. Indian Journal of Chemistry. 2016;55:252-260.

22. Durán-Valle CJ, Fonseca I, Calvino-Casilda V, Picallo M, López-Peinado AJ, Martín-Aranda RM. Sonocatalysis and alkaline-doped carbons: An efficient method for the synthesis of chalcones in heterogeneous media. Catal.Today. 2005;107108:500-506. 